\title{
sciendo
}

\section{Key issues of tranzition to digital entrepreneurship}

\author{
Ruxandra BEJINARU \\ "Stefan cel Mare" University of Suceava, Suceava, Romania \\ ruxandrab@usm.ro
}

\begin{abstract}
Through this paper we want to contribute to the understanding of the main concepts, methods and tools which make possible the transition to a new type of entrepreneurship, namely digital entrepreneurship $(D E)$. The importance of the topical concept, which is an accelerated expanding practice, lies in the fact that a digital business offers opportunities that transcend geographic space, primarily through global online space. The forecasts given to digital entrepreneurship are positive and even aspirational as they anticipate important benefits for the businesses that will create, sell and deliver digitally supported products and services. For the time being, what is presented in the specialized literature are reserved approaches towards the definitions, methodologies or strategies applicable to this type of entrepreneurship, which is in different phases of development on the globe. This research is done according to a simple scheme and we consider it logical in order to understand the transition of entrepreneurship from the knowledge-based economy to digital entrepreneurship. In this approach we proceeded first of all to document the main notions such as: the digitization process and the digitalization phenomenon; the specifics of business in the digital age; digital traction indicators for measuring business success in the digital environment; distinctive features of digital entrepreneurship and we ended with an integrative perspective, formulating recommendations for a successful transition to digital entrepreneurship. We believe that the contribution of this paper is to put together in a clear but concise manner, key aspects that highlight the transition of the traditional business vision to the vision proposed (or actually imposed) by digital entrepreneurship and the era in which we live.
\end{abstract}

Keywords: digitization, digitalization, digital entrepreneurship (DE), digital traction, entrepreneurial skills, strategy, transition, vision.

\section{Introduction}

The field of technology is the one that experiments today the most accelerated development combining knowledge and resources from all fields of science and giving back improved knowledge, products and processes - what we generically call - added value. This new stage of technological development, which implicitly intersects a multitude of other fields (including that of academic education) has been called Industry 4.0 (Amit \& Han, 2017).

The specificity of the 4.0 industry is reciprocity, namely the fact that -developing itself- it produces solutions for other industries- contributing to their improvement. This so-called boomerang effect, actually contributes to the positive stimulation of the economy, business and society as a whole. Industry 4.0 restructures the business environment based on massive digitalization, proposing to the business environment tools such as: artificial intelligence, social media, forums, blogs or various virtual networks. In this context, business people, managers and other actors of economic life must reorganize knowledge management in their organizations so that they remain connected to the flow of knowledge in the new 4.0 industry (Bratianu et al., 2011; Bratianu, Hadad \& Bejinaru, 2020).

The reorganization of business management is necessary and beneficial due to a combination of factors with major influence globally: ease of access to information, flexibility of global labor supply, and most accessibility to consumers in the global market, in any field (Avital et al., 2017; Mahdi et al., 2018). Analyzing the bigger picture, we can state that this is the most

DOI: $10.2478 /$ picbe-2021-0009

(C) 2021 R. Bejinaru, published by Sciendo.

This work is licensed under the Creative Commons Attribution 4.0 License. 
tempting and stimulating offer for any entrepreneur or businessman - access to all potential consumers on the planet. No one can ignore or disregard this advantage - and this is why competition is growing exponentially. This is the major advantage offered by Industry 4.0, among others such as: free and transparent access to knowledge included in the organization, the economy of time, money, space and more.

The importance of this debate lies in the fact that digitalization produces changes both for the structural and relational capital of the organization and for the human capital, in terms of employee behavior, organizational culture and knowledge management practices in their work (Bejinaru \& Iordache, 2011; Bratianu et al., 2020). In this context, we agree with the perspective that digitalization can lead to the optimization of organizational changes based on more efficient communication and collaboration, faster information exchange, more specialized learning and even improving the decision-making process (Bratianu et al., 2021; Dima et al., 2017). To be more easily embraced, the advantages of this global technological phenomenon are presented first, but mass digitalization also has disadvantages and involves risks of knowledge, such as fake news, fabricated data, unconfirmed data, fuzzy knowledge and others (Allcott \& Gentzkow, 2017; Bejinaru, 2019; Bratianu, Prelipcean \& Bejinaru, 2020).

What led us to this debate is the aggressive and immediate impact of digitalization that produces radical, and in some cases even disruptive changes, focusing on completely different values of market players and consumers. In this context, we observe that individual enterprises and entire sectors, public administration, society and national economies are engaged in the game of digital transformation (Ziółkowska, 2020). Based on the hypothesis of the positive and stimulating impact of digitalization on the world in general and on entrepreneurship in particular, we will try to find out the strategies through which digitalization can be successfully implemented in this stage of transition to the digital economy.

\section{Literature review}

\section{The concept, the process and the phenomenon of digitalization}

Business digitalization is a mega trend that has significantly changed the way we live, work and create added value. Digitalization tools are available to everyone today, so organizations can create knowledge networks through which employees with complementary specializations, with different experiences and from different backgrounds can collaborate dynamically and openly to create new knowledge, to develop new processes but specially to become as competitive as possible in the global fight (Costa \& Monteiro, 2016; Vatamanescu et al, 2019).

Maybe, in practical and quite simple terms, to enter the global market, today, all you need is a device and a good internet connection. Starting a new business cannot be conceived without including the digital media. Even traditionally created businesses are now transformed by the mega-trend of digitalization that leads to an advancement of entrepreneurship. Thus, we consider that maintaining a place in the market is an ongoing challenge and entrepreneurs need to be more creative, more flexible and faster. We clarify that, in this research, we used the concept of "business digitalization" with the meaning of - transformations associated with the implementation of digital technology in the business domain. Moreover, the digitalization of business "implies the ability to transform existing products and services into digital variants, which offers superiority over the tangible product" (Parviainen et al., 2017, p.64).

As clear as figure 1 shows, the main goals of digitalization are improvement of the product, automation of the process and simplification of communication. 


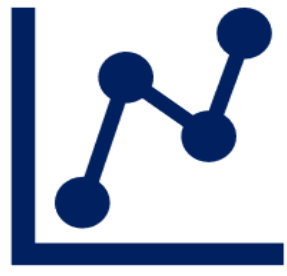

Improvement of the product

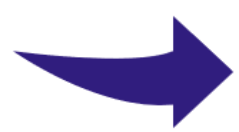

Automation
of the processes

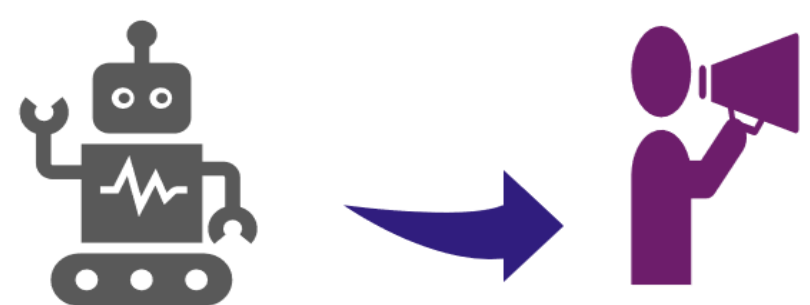

PICBE |

93

Figure 1. Goals of digitalization

Source: adaptation after https://woxapp.com/industries/digitalization-solutions-development/ retrieved on 15.01.2021.

However, in this debate we must also pay attention to the problematic aspects associated with the digitalization of business. In this sense we refer to countless technical and technological difficulties, in direct connection with the operational level of companies' activities, but also difficulties that infer at the managerial level with direct connection on business strategy, employee motivation, marketing policies or collaboration tools and networking (Baesu \& Bejinaru, 2020). For instance, Romania is still at the begging of its digitalization journey and the transition towards an innovative economy and society that incorporates high level technology is still low. Digitalization could be regarded as an optimal solution for political and economic instability by attracting new customers and rising employees' productivity (Hadad \& Bratianu, 2019).

\section{Transformation of business in the digital age}

The magic of entrepreneurship lies in the fact that it gives equal opportunities to all those ambitious enough to learn this trade and to develop over time the necessary skills. In general, the entrepreneur must be a person with a spirit of initiative to draw up short-term and long-term plans and strategies. The entrepreneur must carefully assess the risks and make the best decisions. A defining feature of the entrepreneur is to learn from their own mistakes as well as from the experiences of others. The entrepreneur differs from the ordinary businessman by the fact that he can identify the opportunity of a business able to revolutionize the market. The entrepreneur must have many qualities including visionary thinking, perseverance, curiosity, creativity but also self-motivation. In addition to the above, the successful entrepreneur is always passionate about what he does (Bejinaru, 2018; Bejinaru \& Hapenciuc, 2016; Martinez, Martin \& Marlow, 2018).

Moreover, in a short time, digitalization in the business environment will become an absolute necessity in terms of business profitability and in some cases even in terms of its survival on the market. Business people and managers have conclude that it no longer makes sense to oppose digitalization because it has become universal but it is necessary to approach the incorporation of digitalization into their business in the most serious way. The benefits quickly generated by digitization, such as the saving of human, material, financial and time resources, will leave much behind the businesses that have not adapted or that have delayed the implementation of digitization too much (Li, 2018; Ziółkowska, 2020).

According to the developed practice of digital traction we propose a set of strategic actions for companies to measure the key values of their businesses. In the digital environment, companies are recommended to measure and monitor a mix of essential behavioral values of customers, such 
as the number of users, user activity \& involvement or frequency of use, which reflect the popularity and consequently the act of buying a product or service on the market. It is known that a number of venture capital and private equity firms, such as DFJ, General Atlantic, Monashees Capital or Andreessen Horowitz, implement a specific set of metrics in order to analyze the digital traction of other companies in which they wish to invest. In figure 2 we will present the logical scheme of the digital traction analysis process applied by them (Balocco et al., 2019; World Economic Forum, 2021).

Following this scheme of procedure (Figure 2), the 'scale' is measured for the first time which refers to the number of: visitors, unique users, registered users, the monthly increase of registrations and the organic acquisition of users. Second, 'active use' is measured - which investigates in more detail in order to identify: active users (daily and monthly), the ratio between new users and returning users (or customers), number of returning users (or customers), conversion rate and dropout rate. And the last indicator is the 'commitment' which includes: the promoter's net score (NPS), customer satisfaction index, downloads, keeping the cohort on business specific values, time spent on the site, rejection rate, traffic sources, risk of concentration customer, output rate, photos or videos uploaded, shared, viewed, and number of appreciations and distributions. This digital traction calculation equation is based on ideas drawn from the study of the development and success known by famous pioneers of the digital world - from social networks such as Facebook, Instagram or Twitter, to technology producing companies such as Apple. Even if large investors make extensive use of this digital traction equation - it can be noticed that not all of its elements can be applied to any organization (World Economic Forum, 2021) The bottom line is that digitalization is completely changing the business standards and managers will need to apply a new set of measures to quantify success like large investors in Silicon Valley.

\section{Features of new digital entrepreneurship $(\mathrm{DE})$}

In this discussion, it becomes necessary to explain the distinction between the concepts and practices of 'entrepreneurship in the digital age' (in the context of digitalization) and 'digital entrepreneurship'. As we argued earlier, 'entrepreneurship in the digital age' refers to the transfer of business activities mainly in the digital environment and the gradual insertion of specific strategies for business management in the digital environment. Moreover, in the medium and long term, the dramatic transformation of the management applied by entrepreneurs through the prism of digitalization is foreseen (Bican \& Brem, 2020).

On the other hand, digital entrepreneurship is a topical phrase that wants to describe a new reality, namely the transformation of society and business in accordance with technological advancement. For a rigorous debate of this hybrid concept, namely 'digital entrepreneurship', we must highlight a series of changes on several levels such as philosophy, education and especially entrepreneurial practice (Satalkina \& Steiner, 2020). In practice, keeping pace with the innovative changes brought about by digital technologies may not only provide better opportunities and benefits but may also become disruptive and lead to new vulnerabilities. In principle, digital entrepreneurship includes a series of news and innovations related to entrepreneurship in today's digital world, such as: new methods of market prospecting and customer identification for entrepreneurial projects; new methods to develop and offer products and services; new ways to earn income and lower expenses; new opportunities for collaboration with platforms and partners; as well as new sources of risk and threats. 


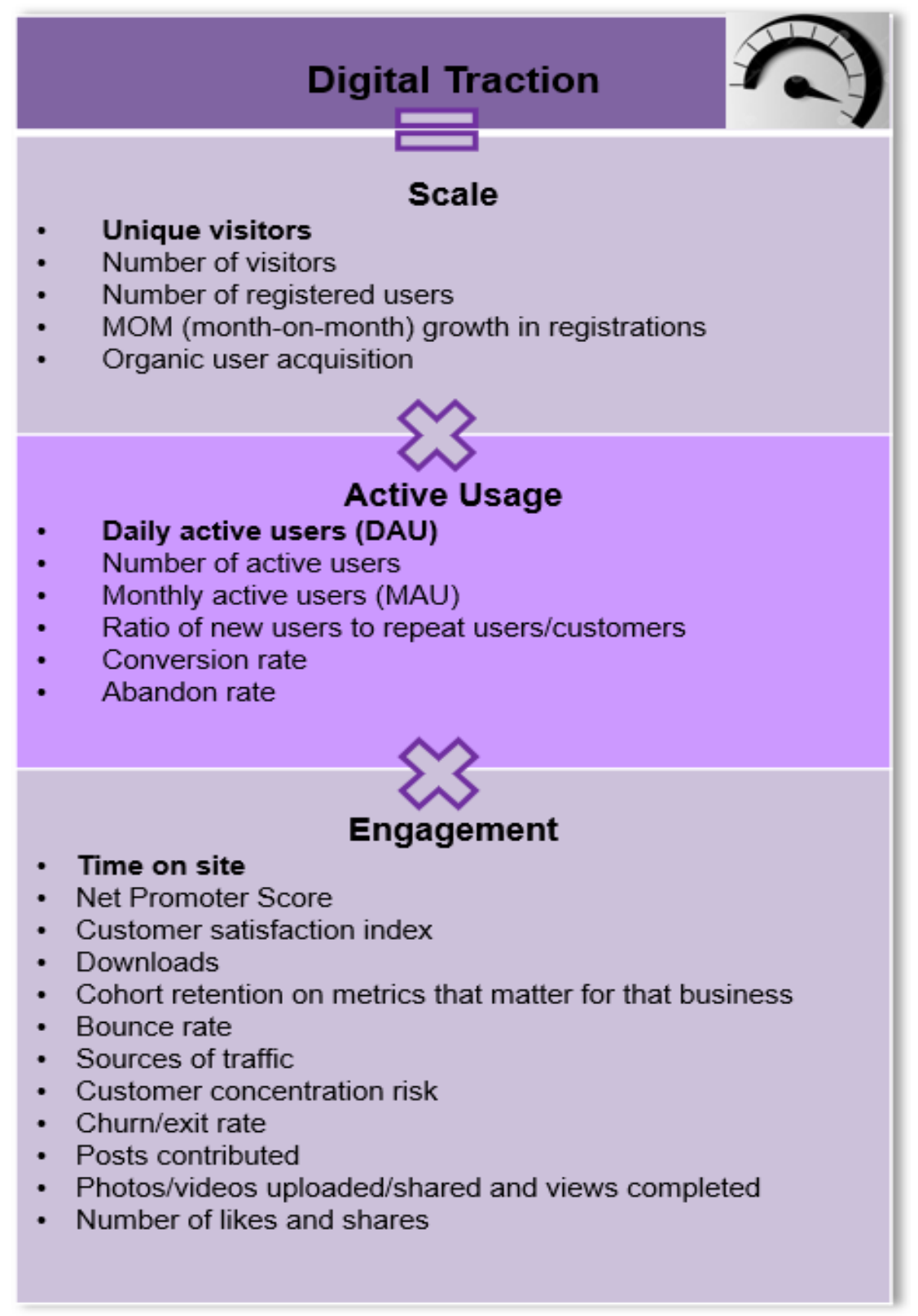

Figure 2. Digital traction scheme

Source: adaptation after weforum.org.

Conceptually, Sahut (et al., 2019) define 'digital entrepreneurship' - as the process of entrepreneurial initiative in order to create digital value by using various socio-technical digital facilities to support efficient procurement, processing, distribution and consumption of digital information. From a practical perspective, digital entrepreneurship has the necessary technical means to strongly encourage potential entrepreneurs and reduce the obstacles between vision and setting up a company, namely technologies such as social media, open-source software and hardware, crowdsourcing, crowdfunding, e-trust and online reputation assessment, 3D printing, digital imaging, and big data (Steininger, 2019). 
The vision that digital entrepreneurship is a form of augmented entrepreneurship (cyber entrepreneurship) is widely accepted in the scientific-academic environment, a vision that we find reflected in the definition adopted by the European Commission, namely:

Digital entrepreneurship includes all new projects and the transformation of existing companies that generate economic and / or social value by creating and using new digital technologies. The specificity of digital enterprises is the intensive use of new digital technologies (especially social, big data, mobile and cloud solutions) in order to improve business operations, invent new business models, improve business intelligence and more efficient interaction with customers and stakeholders. All this creates jobs and growth opportunities for the future (2015).

We emphasize once again the vision according to which digital entrepreneurship cannot be reduced to a simple branch of traditional entrepreneurship (Steininger, 2019). We can argue this vision in terms of the major roles that information and communication technology (ICT) has in digital entrepreneurial operations:

- Role of enabler - enables the operations of enterprises;

- Role of mediator - mediates the operations of new enterprises;

- Role of output - as result of entrepreneurial operations;

- Role of ubiquitous facilitator - facilitates new digital business models.

In conclusion - it becomes obvious that digital entrepreneurship - is a distinct type of entrepreneurship and cannot be expressed only as a subcategory of traditional entrepreneurship.

\section{Discussions}

\section{Implementation of digital entrepreneurship}

From the analyzed literature, we concluded on a set of 3 key elements of digital entrepreneurship: the entrepreneur (attitude, competence, thinking patterns, education and personal background in entrepreneurial actions), entrepreneurial process (digitalization of organizational management, transformations of operational and strategic activities, as well as the establishment of digital startups) and the related ecosystem (which includes external influencing factors such as the infrastructure and institutions that regulate digital entrepreneurship) (Satalkina \& Steiner, 2020). Nowadays, there is no standard profile of the digital entrepreneur. Actually, a couple of traits, with strong influence, which is part of the new entrepreneur's profile refers to his appetite for digital systems and the high degree of confidence he shows for his future success in this digital world. Moreover, the digital entrepreneur is mainly aware, to a greater extent, of the benefits that digitalization offers to the business environment and society (Bandera \& Passerrini, 2020; Giones \& Brem, 2017; Troise \& Tani, 2020).

Even in the digital age, entrepreneurs need to carefully plan business development. The fulfillment of any business vision must be systematized in smart objectives, which will be translated into very clear strategies to be implemented. Digitization does not imply a lack of tact of communication with others. Although the communication process is more digital, communication techniques must also be well chosen whether they are discussions with colleagues or business leaders. The digital business environment can impose various obstacles or problems and a digital entrepreneur must adapt and innovate to find the right solutions to get his business out of the impasse. The digital entrepreneur needs to be much more agile at managing knowledge. The volume of knowledge is much higher in this environment and the sources of information often challenge traps for the inattentive. That is why, especially in the digital age, the entrepreneur does mustn't stop learning. The digital entrepreneur must have a good command of a series of basic 
knowledge and have the ability to manage the continuous learning process because, in a dynamic market, you must keep pace with both customers and competition. For this purpose, specialized SEO services have been set up that digital entrepreneurs can turn to if they identify those trusted partners (Kraus et al., 2018).

Thus, science and practice together, deliver information that personal attitudes are determinants in the evolution of digital entrepreneurs and strongly influence their decisions (Dutot \& Van Horne, 2015). Another important factor is entrepreneurial knowledge and education as well as career aspirations that contribute significantly to supporting the motivation process for involvement in digital entrepreneurship (Farani, A.Y., Karimi, S. \& Motaghed, M. 2017). Although the idea that digital knowledge is the main determining factor for digital entrepreneurship is emphasized (Li, 2018; Zhu \& Lin, 2018), to these are added, depending on the context, the following dimensions: personal attitudes, general skills, decision making or personal success (Anwar \& Daniel, 2016; Martinez, Martin \& Marlow, 2018; Farani, Karimi \& Motaghed, 2017; Heavin \& Power, 2018).

In this order of ideas, a synthetic approach of the defining and generally valid characteristics of digital entrepreneurs are the following (Satalkina \& Steiner, 2020):

I. Personal characteristics and competencies: this category includes the basic features existing at the time of starting a digital business (for example: age, gender, level of education, specific entrepreneurial knowledge, general knowledge about the business environment); and professional traits (adaptability, ability to acquire new skills, availability for lifelong learning);

II. Decision-making and bounded rationality: that refers to the type of attitude in the opportunity-risk equation (for example: appreciation of success, vision and business strategy, perception of business opportunities); personal motivation is also included here, more precisely the entrepreneurial initiatives

III. Personal outcomes: will be reflected mainly through social positioning (for example: transformation of previous social connections and positions, new approaches in cultural norms and traditions); access to new entrepreneurial opportunities (for example: digital inclusion, or the emergence of different social inequalities).

As a bottom-line, we can pose that digital entrepreneurship opens up new business opportunities and at the same time demands new skills of the young generation of entrepreneurs. It is known that the best way to learn entrepreneurship is "by practicing it" and reflecting on one's own experience. Starting a business in the traditional style was very expensive and with a high degree of risk for beginners. Today, the digital world has greatly reduced barriers to new projects and furthermore offers a multitude of ways to success. This is just a different world but one that has a lot to offer to those who will embrace it, adapt and persevere.

Important studies (Bandera \& Passerini, 2020; Ghezzi, 2018; Martinez et al., 2018; Van Laar et al., 2017) on the psychological and behavioral traits of digital entrepreneurs reflect that they are less interested in the future of their business than traditional entrepreneurs and in addition manage to use "neuroticism" to create an advantage. Digital entrepreneurs manage to use anxiety to increase performance, which for traditional entrepreneurs was correlated with risk and lack of performance. Other perspectives are expressed mainly in the direction of self-management skills, like: time management, communication, tech-savviness, self-discipline, flexibility, selfsufficiency, openness, or self-motivation (Ghezzi, 2018; Martinez et al., 2018; Van Laar et al., 2017).

These studies show that in essence, digital entrepreneurs are significantly different from traditional entrepreneurs so research must continue and keep pace with the development of new 
generations in order to better understand their profile and key issues such as motivation for entrepreneurship, type of management applied or stimuli they respond to in a digital ecosystem.

\section{Conclusions}

When we talk about digital entrepreneurship, we cannot look back but only in the future. Digital entrepreneurship will become the norm of the business environment. The younger generations use technology from an early age and already have a lifestyle that includes the digital component to a

greater or lesser extent. Young entrepreneurs will only need to hone their digital skills and digital business education and will certainly become full-fledged digital entrepreneurs.

Through this research paper we reached a series of conclusions on several levels of this important topic such as digital entrepreneurship. The definition of the concept is based on the idea that "digital entrepreneurship includes all new projects and the transformation of existing companies that generate economic and / or social value by creating and using new digital technologies". Thus, even in a new context, the essence of entrepreneurship is the same covering the spirit of initiatives, passion and ambition to achieve goals and agility in adapting to the market.

What can be said about successful strategies in digital entrepreneurship is just speculation for now. The success of digital business has become quantifiable to some extent through digital traction scheme, but it depends very much on the scope and context of the business. The digital world and afterwards digital entrepreneurship started as a strategy of doing business faster, better and to a larger scale and now opportunities and threats are mixed again and require new strategies.

For now, only positive and strong features are presented about the profile of the digital entrepreneur, which paints the image of a digital superhero. However, the digital entrepreneur is a simple man but who has solid knowledge in the field of technology, or more simply is tech-savy, who is ambitious and passionate about the digital environment and who has the vision of digital business. Distinctively, the digital entrepreneur is a daring visionary, a risk-taking and a speed actioning individual. We propose that research on digital entrepreneurship should keep the challenges and opportunities that arise in the near future on the agenda, as these could probably be the only interest of potential new entrepreneurs.

\section{References}

Amit, R., \& Han, X. (2017). Value Creation through Novel Resource Configurations in a Digitally Enabled World. Strategic Entrepreneurship Journal, 11, 228-242.

Allcott, H., \& Gentzkow, M. (2017). Social media and fake news in the 2016 election. Journal of Economic Perspectives, 31(2), 211-36.

Anwar, M.N., \& Daniel, E. (2016). Entrepreneurial marketing in online businesses. Qualitative Market Ressearch International Journal, 19, 310-338.

Avital, M., Mathiassen, L., \& Schultze, U. (2017). Alternative genres in information systems research. European Journal of Information Systems, 26(3), 240-247.

Baesu, C., \& Bejinaru, R. (2020). Knowledge management strategies for leadership in the digital business environment. Proceedings of the International Conference on Business Excellence. 14(1), 646-656, ISSN 2558-9652.

Balocco, R., Cavallo, A., Ghezzi, A., \& Berbegal-Mirabent, J. (2019). Lean business models change process in digital entrepreneurship, Business Process Management Journal, 25(7), 1520-1542. 
Bandera, C., \& Passerini, K. (2020). Personality traits and the digital entrepreneur: Much of the same thing or a new breed?, Journal of the International Council for Small Business, 1(2), 81-105.

Bejinaru, R. (2019). Impact of digitalization in the knowledge economy, Management Dynamics in the Knowledge Economy, 7(3), 367-380.

Bejinaru, R. (2018). Assessing students' entrepreneurial skills needed in the knowledge economy, Management \& Marketing. Challenges for the Knowledge Society, 13(3), 1119-1132.

Bejinaru, R., \& Hapenciuc, C.V. (2016). Valorization of the learning organization's principles in the business HES, Strategica International Conference, Fourth Edition, "Local versus Global - Opportunities and Risks in the Contemporary Business Environment", October $20^{\text {th }}-21^{\text {st }}$, Bucharest: Tritonic, ISBN (E-book): 978-606-749-181-4, 600-611.

Bejinaru, R., \& Iordache Ş. (2011). Intellectual capital dynamics within the learning organization, Proceedings of 3rd European Conference on Intellectual Capital - ECIC, 18-19 April 2011, University Nicosia, Cyprus, 70-77.

Bican, P.M., \& Brem, A. (2020). Digital Business Model, Digital Transformation, Digital Entrepreneurship: Is There A Sustainable "Digital”? Sustainability, 12(13), 5239.

Bratianu, C., Hadad, S. \& Bejinaru, R. (2020). Paradigm shift in business education: A competence-based approach, Sustainability 12(4), 1348.

Bratianu, C., Agapie, A., \& Orzea, I. (2011). Knowledge dynamics modeling using Analytic Hierarchy Process (AHP). In Turner, G., \& Minnone, C. (Eds.). Proceedings of the $3^{\text {rd }}$ European Conference on Intellectual Capital, 18-19 April 2011, University of Nicosia, Cyprus, 94-102.

Bratianu, C., Prelipcean, G., \& Bejinaru, R. (2020). Exploring the latent variables which support SMEs to become learning organizations, Management \& Marketing. Challenges for the Knowledge Society, 15(2), 154-171.

Bratianu, C., Nestian, A.S., Tita, S.M., Voda, A.I., \& Guta, A.L. (2020). The impact of knowledge risk on sustainability of firms. Amfiteatrul Economic, 22(55), 639-652.

Bratianu, C., Vatamanescu, E.M., Anagnoste, S., \& Dominici, G. (2021). Untangling knowledge fields and knowledge dynamics within the decision-making process. Management Decision, 59(2), 306.

Costa, V., \& Monteiro, S. (2016). Key knowledge management processes for innovation: a systematic literature review. VINE Journal of Information and Knowledge Management Systems, 46(3),386.

Dima, A.M., Hadad, S., \& Luchian, I. (2017). Review on the dimensions of business-university alliances, Proceedings of the International Conference on Business Excellence, 11(1), 64-73.

Dutot, V., \& Van Horne, C. (2015). Digital Entrepreneurship Intention in a Developed vs. Emerging Country:An Exploratory Study in France and the UAE, Transnational Corporations Review, 7, 79.

European Commission (2015). Digital transformation of European industry and enterprises: a report of the strategic policy forum on digital entrepreneurship. available from: http://ec.europa.eu/DocsRoom/documents/9462/attachments/1/translations/en/renditions/ native. 
Farani, A.Y., Karimi, S., \& Motaghed, M. (2017). The role of entrepreneurial knowledge as a competence in shaping Iranian students' career intentions to start a new digital business. European Journal of Training and Development, 41, 83-100.

Ghezzi, A. (2018). Digital startups and the adoption and implementation of Lean Startup Approaches: E_ectuation, Bricolage and Opportunity Creation in practice. Technological Forecasting and Social Change, 146, 945-960.

Giones, F., \& Brem, A. (2017). Digital Technology Entrepreneurship: A Definition and Research Agenda, Technology Innovation Management Review, 7(5).

Hadad, S., \& Bratianu, C. (2019). Dematerialization of banking products and services in the digital era, Management \& Marketing. Challenges for the Knowledge Society, 14(3), 318-337.

Heavin, C., \& Power, D.J. (2018). Challenges for digital transformation - towards a conceptual decision support guide for managers. Journal of Decision Systems, 27, 38-45.

Kraus, S., Palmer, C., Kailer, N., Kallinger, F.L., \& Spitzer, J. (2018). Digital entrepreneurship: A research agenda on new business models for the twenty-first century, International Journal of Entrepreneurial Behavior \& Research, Vol. ahead-of-print No. ahead-of-print.

Li, F. (2018). The digital transformation of business models in the creative industries: A holistic framework and emerging trends. Technovation, 92, 102012.

Mahdi, O. R., Nassar, I. A., \& Almsafir, M. K. (2018). Knowledge management processes and sustainable competitive advantage: An empirical examination in private universities. Journal of Business Research.

Martinez Dy, A., Martin, L., \& Marlow, S. (2018). Emancipation through digital entrepreneurship? A critical realist analysis. Organization, 25, 585-608.

Parviainen, P., Tihinen, M., Kääriäinen, J., \& Teppola, S. (2017). Tackling the digitalization challenge: how to benefit from digitalization in practice, International Journal of Information Systems and Project Management, 5(1), 63-77.

Sahut, J. M., Iandoli, L., \& Teulon, F. (2019). The age of digital entrepreneurship. Small Business Economics, 1-11. Springer.

Satalkina, L., \& Steiner, G. (2020). Digital Entrepreneurship and its Role in Innovation Systems: A Systematic Literature Review as a Basis for Future Research Avenues for Sustainable Transitions. Sustainability, 12, 2764.

Steininger, D. M. (2019). Linking information systems and entrepreneurship: a review and agenda for IT associated and digital entrepreneurship research. Information Systems Journal, 29, 363-407.

Troise, C., \& Tani, M. (2020). Exploring entrepreneurial characteristics, motivations and behaviours in equity crowdfunding: some evidence from Italy, Management Decision, Vol. ahead-of-print No. ahead-of-print.

Van Laar, E., Van Deursen, A.J., Van Dijk, J.A., \& De Haan, J. (2017). The relation between $21^{\text {st }}$ century skills and digital skills: A systematic literature review. Computers in Human Behavior, 72, 577-588.

Vatamanescu, E.M., Andrei, A.G., Nicolescu, L., Pînzaru, F., \& Zbuchea, A. (2017). The influence of competitiveness on smes internationalization effectiveness. Online versus offline business networking. Information Systems Management, 34(3), 205-219.

World Economic Forum (2021). How to measure success in the digital age, retrieved online 21 January 2021, https://reports.weforum.org/digital-transformation/how-to-measure-success -in-the-digital-age/.

DOI: 10.2478/picbe-2021-0009, pp. 91-101, ISSN 2558-9652 |

Proceedings of the $15^{\text {th }}$ International Conference on Business Excellence 2021 
Ziółkowska, B. (2020). Managers’ decisions and strategic actions of enterprises in Poland in the face of digital transformation. Ekonomia i Prawo. Economics and Law, 19(4), 817-825.

Zhu, Z., \& Lin, S.-F. (2018). Understanding entrepreneurial perceptions in the pursuit of emerging e-business opportunities: The dimensions and drivers. Computers in Human Behavior, 95, 252-261. 